\title{
MACRO NEWS AND COMMODITY RETURNS
}

\author{
GUGLIELMO MARIA CAPORALE* ${ }^{\dagger}$, FABIO SPAGNOLO and NICOLA SPAGNOLO \\ Department of Economics and Finance, Brunel University London, Uxbridge, UK
}

\begin{abstract}
This paper adopts a vector autoregression-generalized autoregressive conditional heteroscedasticity approach to model the dynamic linkages between both mean and variance of macro news and commodity returns (Gold, Corn, Wheat, Soybeans, Silver, Platinum, Palladium, Copper, Aluminium and Crude Oil) over the period 01/01/2001-26/09/2014. The chosen specification also controls for the effect of the exchange rate. The results can be summarized as follows. Mean spillovers running from news to commodity returns are positive with the exception of Gold and Silver. Volatility spillovers are bigger in size and affect most commodity returns. Both first-moment and second-moment linkages are stronger in the post-September 2008 period. Overall, our findings confirm that commodities, despite not being financial assets, are sensitive to macro news (especially their volatility) and also suggest that the global financial crisis has strengthened such linkages. Copyright @ 2016 John Wiley \& Sons, Ltd.
\end{abstract}

Received 17 September 2015; Revised 11 April 2016; Accepted 13 September 2016

JEL CODE: C32; F36; G15

KEY WORDS: macro news; commodity prices; VAR-GARCH model

\section{INTRODUCTION}

The existing literature on the effects of macro news mainly focuses on the stock and bond markets and typically considers two sources of news effects: scheduled macroeconomic announcements that do not correspond to agents' expectations (the announcement effect) and unscheduled announcements (the surprise effect). Most studies analyse the former, calculating the difference between news releases and their expected value, and then defining positive and negative news accordingly (Kocenda and Hanousek, 2011, and Hanousek et al., 2009). Stock prices have been shown to be affected by news about monetary variables such as money growth and interest rates (e.g. Chen, 1991; Cornell, 1983; Pearce and Roley, 1983, 1985), and in some cases also by real-sector news (e.g. McQueen and Roley, 1993, and Boyd et al., 2005). Birz and Lott (2011) use newspaper headlines and also find that news on GDP and unemployment affect stock returns. Caporale et al. (2014a) consider both mean and volatility spillovers in the case of the euro area.

Various studies have also been carried out for bond markets. For instance, Gurkaynak et al. (2005) show that long-term interest rates respond to the unexpected component of macro and monetary news releases, Balduzzi et al. (2001) and Andersen et al. (2005) find effects on US Treasury bond futures contracts, and Brenner et al. (2009) on bond return volatility. Beetsma et al. (2013) examine the impact of news on interest rate spreads vis-à-vis Germany in various countries in the euro area, and Caporale et al. (2014b) provide evidence of dynamic linkages in both first and second moments.

Fewer studies have examined the effects of macro news on commodity prices. Despite not being financial assets, the latter have been shown to be affected by variables such as interest rates (Frankel, 2008) and the US dollar exchange rate, both of which are known to respond to news announcements. Frankel and Hardouvelis (1985) provide evidence of a statistically significant response to US money supply announcements; effects of macro news on various commodity prices are also found by Cai et al. (2001), Hess et al. (2008), Kilian and Vega (2008);

\footnotetext{
* Correspondence to: Guglielmo Maria Caporale, Department of Economics and Finance, Brunel University London, Uxbridge, UK.

$\dagger$ E-mail:Guglielmo-Maria.Caporale@brunel.ac.uk
} 
commodities futures prices have been reported to be affected as well (Barnhart, 1989; Ghura, 1990). Roache and Rossi (2009) in particular show that they are influenced by the surprise element in macro news, with evidence of a pro-cyclical bias after controlling for the effects of the US dollar, the only exception being gold, which reacts counter-cyclically given its role as a safe heaven and store of value and is more sensitive to bad news and higher uncertainty. Unlike most other authors, typically using OLS, they estimate a generalized autoregressive conditional heteroscedasticity $(\mathrm{GARCH})(1,1)$ model given the evidence of time variation and clustering of volatilities (Cai et al., 2001, is another of the few papers using a GARCH framework, specifically to examine the impact of news on gold futures prices).

Some recent literature focuses on investor psychology to explain the relationship between news and financial markets. For instance, De Long et al. (1990) distinguish between two categories of traders: rational arbitrageurs updating their Bayesian beliefs on the basis of economic fundamentals, and noise traders with random beliefs. In their model, because of risk aversion and other constraints for investors, low sentiment has a (temporary) negative effect on prices but increases volume, as noise traders react to negative belief shocks by selling shares to rational arbitrageurs (Campbell et al., 1993). Coval and Shumway (2001) and Antweiler and Frank (2004) instead relate investor sentiment to trading costs, with the perception of a more negative outlook resulting in lower trading volumes.

Tetlock (2007) examines the links between media 'pessimism' (generated by 'bad news') and low-investor sentiment in the USA by estimating a VAR model. The former could be interpreted as a proxy for either investor sentiment or risk aversion, in which case pessimism should increase volume, or for trading costs, implying that pessimism should decrease volume. Also, pessimism could either forecast future or reflect past sentiment, and be due to negative information about asset prices not already incorporated in them or about dividends already reflected in them, with different implications for price behaviour. The empirical evidence suggests that models of noise and liquidity traders can account for the effects of low-investor sentiment on financial markets (see also Tetlock et al., 2008, for further results). ${ }^{1}$ Fang and Peress (2009) use a wider dataset including more US daily newspapers and a cross-section of countries and find that media coverage can increase the degree of recognition and therefore the corresponding returns on stocks only recognized by a few agents and consequently not sufficiently diversified; therefore, it affects asset prices by disseminating information broadly, even if it does not represent news (Merton, 1987).

Some further issues are examined in the most recent literature on the impact of news on financial variables in general. For instance, Pericoli and Veronese (2016) use the dispersion of analysts' forecasts to proxy heterogeneity in agents' beliefs and analyse how this affects the response of the US dollar/euro exchange rate as well as the US and German long-term interest rates from 1999 to 2014. They find that news surprises have a stronger effect when forecaster heterogeneity is lower, regardless of the frequency. Other studies such as Huang (2015) use highfrequency data to show that the reaction of markets to news can vary depending on the economic situation, financial systemic risk and the zero-lower-bound policy. In another paper, Fuss et al. (2015) introduce a new information density indicator to understand better price reactions to news and price jumps in particular. Theirs is essentially a measure of additional uncertainty in the market, which is reduced by 'hard' facts in the form of macro news. Finally, Cakan et al. (2015) analyse the impacts of US macroeconomic announcement surprises on the volatility of 12 emerging stock markets by employing asymmetric Glosten, Jagannathan, and Runkle-GARCH model with both positive and negative surprises about inflation and unemployment rate announcements in the USA. They find that volatility shocks are persistent and asymmetric volatility increases with bad news on US inflation and unemployment in at least a few cases, whilst it decreases with good news about US employment in most cases.

The present paper adopts a vector autoregression (VAR)-GARCH approach to model the dynamic linkages between both mean and variance of macro news and commodity returns. This is in contrast to the vast majority of earlier contributions, which only examined level effects. Analysing simultaneously the interactions between the first and second moments sheds new light on the issues of interest. The layout of the paper is the following. Section 2 outlines the econometric modelling approach. Section 3 describes the data and presents the empirical findings. Section 4 summarizes the main findings and offers some concluding remarks.

\section{THE MODEL}

We represent the first and second moments of commodity returns and news using a VAR-GARCH(1,1). ${ }^{2}$ In its most general specification, the model takes the following form: 


$$
\mathbf{x}_{i, t}=\alpha+\beta x_{i, t-1}+\delta \mathrm{f}_{t-1}+\mathbf{u}_{t}
$$

where $\mathbf{x}_{i, t}=\left(\right.$ Com mod ity $\operatorname{Ret}_{i, t}$, PositiveNews $_{t}$, NegativeNews $\left._{t}\right)$ and $\mathbf{x}_{i, t-1}$ is a corresponding vector of lagged variables. ${ }^{3}$ We control for the exchange rate by including in the mean equation the federal reserve US dollar trade weighted index against major currencies, $\mathbf{f}_{t-1}=\left(U S\right.$ exrate $\left._{t-1}\right)$. The residual vector $\mathbf{u}_{t}=\left(e_{1, t}, e_{2, t}, e_{3, t}\right)$ is trivariate and normally distributed $\mathbf{u}_{t} \mid I_{t-1} \sim\left(\mathbf{0}, H_{t}\right)$ with its corresponding conditional variance covariance matrix given by

$$
H_{t}=\left[\begin{array}{lll}
h_{11 t} & h_{12 t} & h_{13 t} \\
h_{12 t} & h_{22 t} & h_{23 t} \\
h_{13 t} & h_{23 t} & h_{33 t}
\end{array}\right]
$$

The parameter vectors of the mean return Equation (1) correspond to the constant $\alpha=\left(\alpha_{1}, \alpha_{2}, \alpha_{3}\right)$, and the autoregressive term, $\boldsymbol{\beta}=\left(\beta_{11}, \beta_{12}+\beta_{12}^{*}, \beta_{13}+\beta_{13}^{*}\left|0, \beta_{22}, 0\right| 0,0, \beta_{33}\right)$, which allows for commodity mean return effects from positive $\left(\beta_{12}\right)$ and negative $\left(\beta_{13}\right)$ news. Furthermore, $\delta$ measures the effect of the exchange rate and appears in the first equation only. The parameter matrices for the variance Equation (2) are defined as $C_{0}$, which is restricted to be upper triangular, and the two unrestricted matrices $A_{11}$ and $G_{11}$. In order to account for the possible effects of the recent financial crisis, we include a dummy variable (denoted by ${ }^{*}$ ) with a switch on 15 September 2008, that is, on the day of the collapse of Lehman Brothers. Therefore, the second moment will take the following form ${ }^{4}$ :

$$
H_{t}=C_{0}^{\prime} C_{0}+A_{11}^{\prime}\left[\begin{array}{ccc}
e_{1, t-1}^{2} & e_{2, t-1} e_{1, t-1} & e_{3, t-1} e_{1, t-1} \\
e_{1, t-1} e_{2, t-1} & e_{2, t-1}^{2} & e_{3, t-1} e_{2, t-1} \\
e_{1, t-1} e_{3, t-1} & e_{2, t-1} e_{3, t-1} & e_{3, t-1}^{2}
\end{array}\right] A_{11}+G_{11}^{\prime} H_{t-1} G_{11}
$$

where

$$
A_{11}=\left[\begin{array}{ccc}
a_{11} & 0 & 0 \\
a_{21}+a_{21}^{*} & a_{22} & 0 \\
a_{31}+a_{31}^{*} & 0 & a_{33}
\end{array}\right] ; G_{11}=\left[\begin{array}{ccc}
g_{11} & 0 & 0 \\
g_{21}+g_{21}^{*} & g_{22} & 0 \\
g_{31}+g_{31}^{*} & & g_{33}
\end{array}\right]
$$

Equation (3) models the dynamic process of $H_{t}$ as a linear function of its own past values $H_{t-1}$ and past values of the squared innovations $\left(e_{1, t-1}^{2}, e_{2, t-1}^{2}, e_{3, t-1}^{2}\right)$. The parameters of (3) are given by $C_{0}$, which is restricted to be upper triangular, and the two matrices $A_{11}$ and $G_{11}$. Each of them has four zero restrictions because we are focusing on volatility spillovers (causality-in-variance) running from positive news before $\left(a_{21}\right)$ and after the crisis $\left(a_{21}+a_{21}^{*}\right)$, as well as from negative news before $\left(a_{31}\right)$ and after the crisis $\left(a_{31}+a_{31}^{*}\right)$, to stock returns. The BEKK representation guarantees by construction that the covariance matrix in the system is positive definite. Given a sample of $T$ observations, a vector of unknown parameters $\theta$ and a $3 \times 1$ vector of variables $\mathbf{x}_{t}$, the conditional density function for model (1) is as follows:

$$
f\left(\mathbf{x}_{t} \mid I_{t-1} ; \theta\right)=(2 \pi)^{-1}\left|H_{t}\right|^{-1 / 2} \exp \left(-\frac{\mathbf{u}_{t}^{\prime}\left(H_{t}^{-1}\right) \mathbf{u}_{t}}{2}\right)
$$

The log-likelihood function is

$$
L=\sum_{t=1}^{T} \log f\left(\mathbf{x}_{t} \mid I_{t-1} ; \theta\right)
$$

where $\theta$ is the vector of unknown parameters. The standard errors are calculated using the quasi-maximum likelihood method of Bollerslev and Wooldridge (1992), which is robust to the distribution of the underlying residuals. 


\section{EMPIRICAL ANALYSIS}

\subsection{Data}

We use daily data (from Bloomberg) for 10 commodities (Gold, Corn, Wheat, Soybeans, Silver, Platinum, Palladium, Copper, Aluminium and Crude Oil) over the period 01/01/2001-26/09/2014, for a total of 3582 observations. Furthermore, as already mentioned, we control for the exchange rate, which is defined as the Federal Reserve US dollar trade weighted index against major currencies, the data source being the St Louis Federal Reserve website. We construct daily returns as the logarithmic differences of commodity prices.

We consider news coverage of four macro economic data series, that is, GDP, unemployment, retail sales and durable goods (Birz and Lott, 2011). The data for the News Index are collected from Bloomberg where news coverage is proxied by story headline counts. News headlines were selected using an extensive search string, containing words indicating articles dealing with macro variables. In order to obtain data on the frequency of articles dealing with economic issues within our sample, we searched for and discriminated between articles with potentially positive or potentially negative connotations towards GDP, unemployment, retail sales and durable goods. The average number of stories about unemployment and GDP is very similar; these account for the majority of news articles, whereas there is less coverage of retail sales and durable goods releases. The index we use does not distinguish between different types of macro news; because the focus of this study is on the effects of positive

Table 1. Descriptive statistics and LM-ARCH test

\begin{tabular}{|c|c|c|c|c|c|}
\hline & \multicolumn{2}{|c|}{ Pre-2008 } & \multicolumn{2}{|c|}{ Post-2008 } & \multirow[b]{2}{*}{ LM-Tes } \\
\hline & Mean & Std. dev & Mean & Std. dev & \\
\hline \multicolumn{6}{|c|}{ News } \\
\hline Positive Index & 1.601 & 0.891 & 2.034 & 0.674 & $\begin{array}{l}41.237 \\
(0.000)\end{array}$ \\
\hline Negative Index & 1.548 & 0.857 & 2.045 & 0.696 & $\begin{array}{l}84.999 \\
(0.000)\end{array}$ \\
\hline$\%$ Positive & 0.507 & 0.049 & 0.499 & 0.036 & \\
\hline$\%$ Negative & 0.493 & 0.049 & 0.501 & 0.036 & \\
\hline \multicolumn{6}{|c|}{ Commodities } \\
\hline Alluminium & 0.033 & 1.275 & -0.043 & 1.541 & $\begin{array}{l}31.475 \\
(0.000)\end{array}$ \\
\hline Copper & 0.093 & 1.681 & -0.003 & 2.002 & $\begin{array}{c}85.953 \\
(0.0000)\end{array}$ \\
\hline Corn & 0.067 & 1.464 & -0.018 & 1.944 & $\begin{array}{l}53.054 \\
(0.000)\end{array}$ \\
\hline Gold & 0.069 & 1.074 & 0.022 & 1.265 & $\begin{array}{l}40.370 \\
(0.000)\end{array}$ \\
\hline Oil & 0.097 & 2.099 & -0.001 & 2.109 & $\begin{array}{l}31.021 \\
(0.000)\end{array}$ \\
\hline Palladium & 0.061 & 2.128 & 0.053 & 2.127 & $\begin{array}{c}139.761 \\
(0.000)\end{array}$ \\
\hline Platinum & 0.085 & 1.307 & -0.019 & 1.585 & $\begin{array}{l}115.68 \\
(0.000)\end{array}$ \\
\hline Silver & 0.066 & 1.713 & 0.021 & 2.392 & $\begin{array}{l}99.419 \\
(0.000)\end{array}$ \\
\hline Soybeans & 0.056 & 1.487 & 0.023 & 1.638 & $\begin{array}{l}88.421 \\
(0.000)\end{array}$ \\
\hline Wheat & 0.069 & 1.723 & -0.011 & 2.064 & $\begin{array}{c}313.383 \\
(0.000)\end{array}$ \\
\hline
\end{tabular}

Note: Commodity returns are the daily percentage changes in the market closing values. The number of positive (negative) newspaper headlines index is defined as follows: positive (negative) news index $=\ln [\mathrm{e}+\mathrm{USA}$ positive (negative) news + Eurozone positive (negative) news]. Min and max values refer to the news index. The sample size covers the period 01/1/2001-26/9/2014, for a total of 3582 observations. LM-Arch $p$-values are reported in brackets. 
and negative macro news respectively as reported and interpreted by the media, we use news released in countries recognized as mainly commodity importers. ${ }^{5}$ The daily positive (negative) news index is defined as follows:

$$
\begin{aligned}
\text { Positive (Negative) News Index }= & \ln [\mathbf{e}+\text { USA positive (negative) news } \\
& + \text { Eurozone positive (negative) news }]
\end{aligned}
$$

Table 1 presents several descriptive statistics for the two sub-samples, before and after the 2008 crisis. The mean returns are positive for all commodities; in particular, copper, oil and platinum have higher returns than the other commodities. It is clear that returns for all commodities were severely hit by the 2008 crisis, and their returns fell in comparison with the pre-September 2008 period. In some cases (aluminium, copper, corn, oil, platinum and wheat), negative returns are observed. As for the second moment, all commodities are characterized by higher volatility in the post-September 2008 sub-sample. Visual inspection of commodity returns (Figures 1 and 2) confirms the
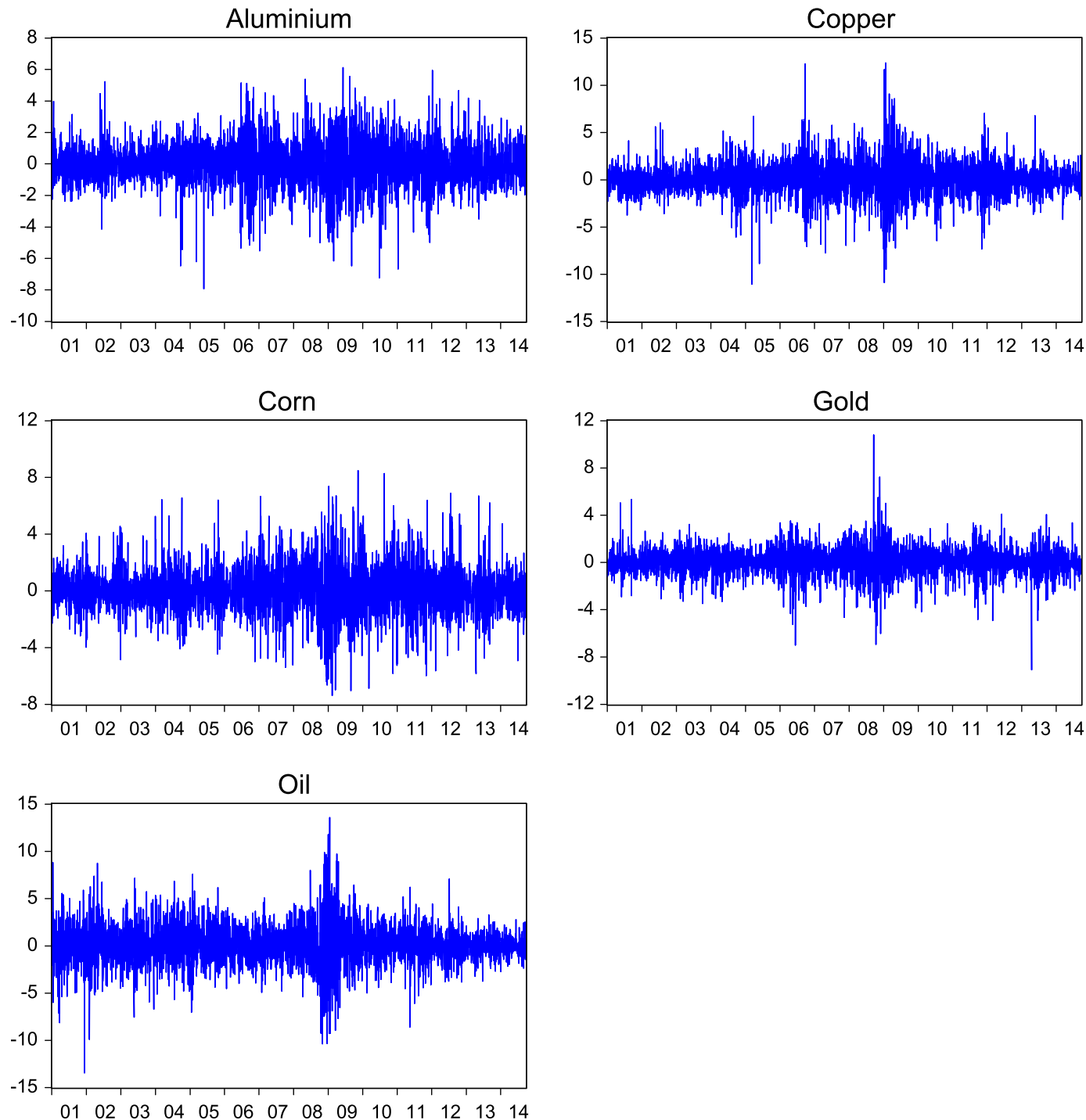

Figure 1. Commodity returns. 

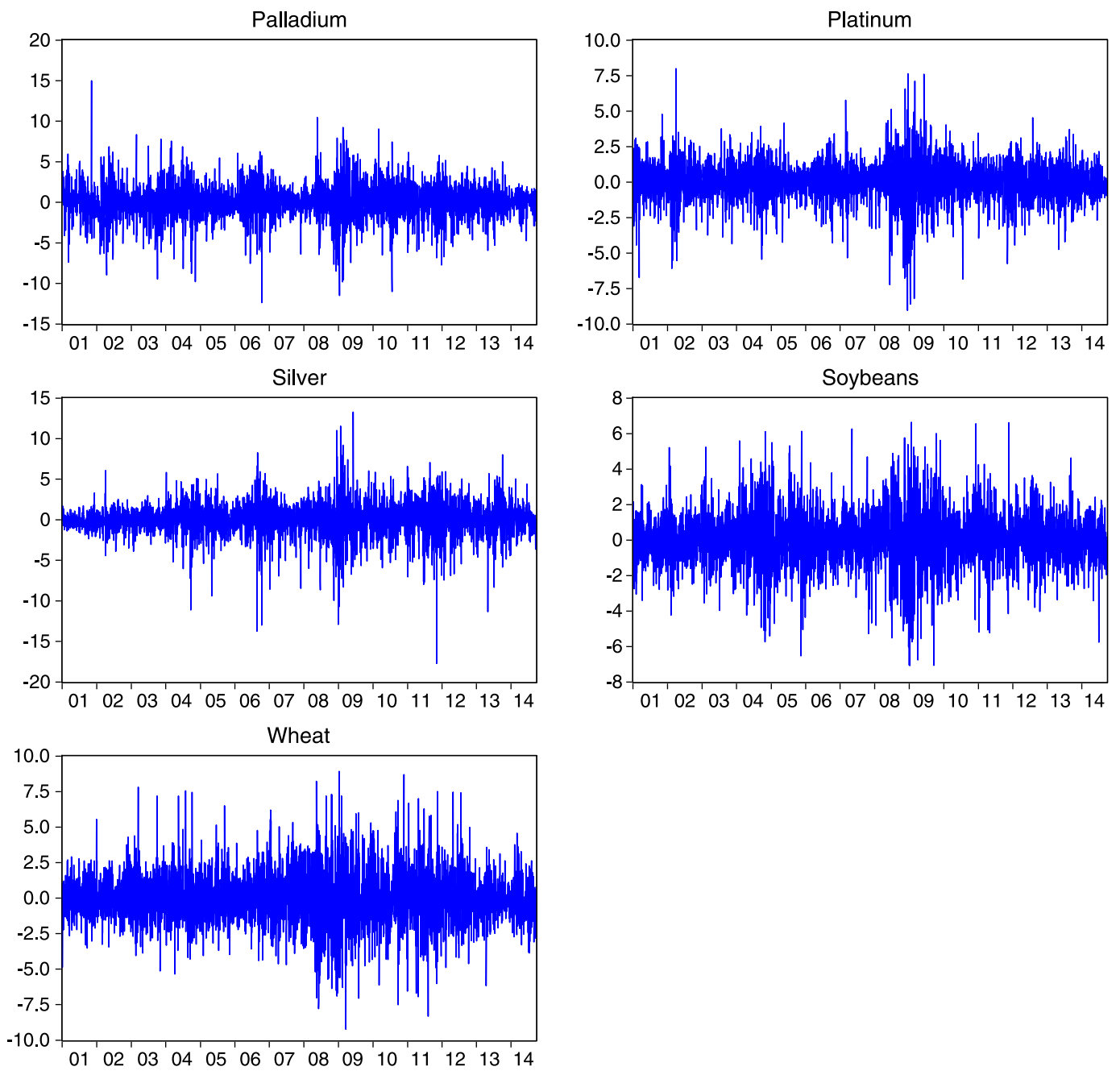

Figure 2. Commodity returns.

marked increase in volatility after September 2008. This evidence that the behaviour of the first and second moment for all commodities changed substantially from the first to the second sub-sample motivates the inclusion of a dummy variable to control for structural breaks in the causality dynamics.

The news index (for negative and positive news) also exhibits a clear structural break, with a higher number of news releases in the post-September 2008 crisis. This is not surprising, because the global financial crisis was covered extensively in the media. Please note that a news index equal to 2 means a total of 100 USA and Eurozone news. Furthermore, in Table 1, we report the percentage of positive and negative news over the total. The percentage of negative was below $50 \%$ of the total before the crisis, and above that threshold during the crisis.

Before estimating our model, LM-Arch tests have been performed and reported in Table 1. The results provide strong evidence of a time-varying conditional variance for all the series under investigation.

\subsection{Hypotheses tested}

We test for mean and volatility spillovers by placing restrictions on the relevant parameters; specifically, we consider the following two sets of null hypotheses ${ }^{6} \mathrm{H}_{0}$ : 
Table 2. Estimated VAR-GARCH(1,1) model

\begin{tabular}{|c|c|c|c|c|}
\hline & \multicolumn{2}{|c|}{ Aluminium } & \multicolumn{2}{|c|}{ Copper } \\
\hline & Coefficient & $p$-values & Coefficient & $p$-values \\
\hline & \multicolumn{4}{|c|}{ Conditional Mean Equation } \\
\hline$\alpha_{1}$ & -0.002 & $(0.972)$ & 0.015 & $(0.772)$ \\
\hline$\alpha_{2}$ & 1.723 & $(0.001)$ & 1.724 & $(0.001)$ \\
\hline$\alpha_{3}$ & 1.715 & $(0.001)$ & 1.714 & $(0.001)$ \\
\hline$\beta_{11}$ & 0.001 & $(0.077)$ & -0.064 & $(0.001)$ \\
\hline$\beta_{12}$ & 0.084 & $(0.248)$ & 0.059 & $(0.327)$ \\
\hline$\beta_{12}^{*}$ & 0.256 & $(0.049)$ & 0.123 & $(0.294)$ \\
\hline$\beta_{13}$ & -0.121 & $(0.011)$ & -0.077 & $(0.215)$ \\
\hline$\beta_{13}^{*}$ & -0.307 & $(0.034)$ & -0.106 & $(0.361)$ \\
\hline \multirow[t]{2}{*}{$\delta$} & -1.372 & $(0.048)$ & -2.805 & $(0.061)$ \\
\hline & \multicolumn{4}{|c|}{ Conditional Variance Equation } \\
\hline$c_{11}$ & 0.001 & $(0.001)$ & 0.001 & $(0.004)$ \\
\hline$c_{22}$ & 0.001 & $(0.003)$ & 0.001 & $(0.002)$ \\
\hline$c_{33}$ & 0.003 & $(0.002)$ & 0.001 & $(0.001)$ \\
\hline$g_{11}$ & -0.981 & $(0.001)$ & -0.978 & $(0.001)$ \\
\hline$g_{21}$ & 0.016 & $(0.001)$ & 0.044 & $(0.001)$ \\
\hline$g_{21}^{*}$ & 0.006 & $(0.597)$ & 0.041 & $(0.001)$ \\
\hline$g_{22}$ & 0.991 & $(0.001)$ & -0.990 & $(0.031)$ \\
\hline$g_{31}$ & 0.986 & $(0.001)$ & -0.991 & $(0.001)$ \\
\hline$g_{31}^{*}$ & 0.006 & $(0.001)$ & 0.038 & $(0.044)$ \\
\hline$g_{33}$ & 0.011 & $(0.001)$ & 0.042 & $(0.001)$ \\
\hline$a_{11}$ & -0.176 & $(0.001)$ & 0.201 & $(0.001)$ \\
\hline$a_{21}$ & -0.014 & $(0.035)$ & 0.016 & $(0.003)$ \\
\hline$a_{21}^{*}$ & 0.015 & $(0.041)$ & -0.012 & $(0.036)$ \\
\hline$a_{22}$ & 0.128 & $(0.001)$ & -0.121 & $(0.001)$ \\
\hline$a_{31}$ & -0.015 & $(0.050)$ & 0.011 & $(0.002)$ \\
\hline$a_{31}^{*}$ & -0.016 & $(0.049)$ & 0.016 & $(0.001)$ \\
\hline$a_{33}$ & 0.131 & $(0.001)$ & 0.125 & $(0.001)$ \\
\hline LogLik & -11491.22 & & -11131.19 & \\
\hline$L B_{\text {Comm.,(10) }}$ & 7.1261 & & 8.4563 & \\
\hline$L B_{\text {Comm.,(10) }}$ & 9.2298 & & 7.1351 & \\
\hline
\end{tabular}

Note: Standard errors (S.E.) are calculated using the quasi-maximum likelihood method of Bollerslev and Wooldridge 1992, which is robust to the distribution of the underlying residuals. Parameters not statistically significant at $10 \%$ level are not reported. LB Comm.(10) and LB $2_{\text {Comm.(10) }}^{2}$ are the Ljung and Box (1978) of significance of autocorrelations of 10 lags in the standardized and standardized squared residuals, respectively. The parameters $\beta_{12}$ and $\beta_{13}$ measure the causality effect of positive and negative news on commodity returns, respectively. $a_{21}$ and $a_{31}$ measure the causality in variance effect of positive and negative news, respectively, whereas $\theta_{12}$ and $\theta_{13}$ capture the effect of positive and negative news volatility on commodity returns. The effect of the 2008 financial crises on commodities is measured by $\left(\beta_{12}+\beta_{12}^{*}\right)$ and $\left(\beta_{13}+\beta_{13}^{*}\right)$, whereas $\left(a_{21}+a_{21}^{*}\right)$ and $\left(a_{31}+a_{31}^{*}\right)$ capture the effect on commodity return volatilities. The covariance stationarity condition is satisfied by all the estimated models, all the eigenvalues of $A_{11} \otimes A_{11}+G_{11} \otimes G_{11}$ being less than one in modulus. Note that in the conditional variance equation the sign of the parameters cannot be determined. 
1. Tests of no mean spillovers from news to commodity returns

$H_{01}$ : Positive news to commodity returns before the 2008 crisis: $\beta_{12}=0$

$H_{02}$ : Positive news to commodity returns after the 2008 crisis: $\beta_{12}^{*}=0$

$H_{03}$ : Negative news to commodity returns before the 2008 crisis: $\beta_{13}=0$

$H_{04}$ : Negative news to commodity returns after the 2008 crisis: $\beta_{13}^{*}=0$

2. Tests of no volatility spillovers from news to commodity returns

$H_{05}$ : Positive news volatility to commodity volatility before the 2008 crisis: $a_{21}=g_{21}=0$

$H_{06}$ : Positive news volatility to commodity volatility after the 2008 crisis: $a_{21}^{*}=g_{21}^{*}=0$

$H_{07}$ : Negative news volatility to commodity volatility before the 2008 crisis: $a_{31}=g_{31}=0$

$H_{08}$ : Negative news volatility to commodity volatility after the 2008 crisis: $a_{31}^{*}=g_{31}^{*}=0$

Table 3. Estimated VAR-GARCH(1,1) model

\begin{tabular}{|c|c|c|c|c|}
\hline & \multicolumn{2}{|c|}{ Corn } & \multicolumn{2}{|c|}{ Gold } \\
\hline & Coefficient & $p$-values & Coefficient & $p$-values \\
\hline & \multicolumn{4}{|c|}{ Conditional Mean Equation } \\
\hline$\alpha_{1}$ & -0.044 & $(0.408)$ & 0.103 & $(0.002)$ \\
\hline$\alpha_{2}$ & 1.726 & $(0.001)$ & 1.725 & $(0.001)$ \\
\hline$\alpha_{3}$ & 1.716 & $(0.001)$ & 1.715 & $(0.001)$ \\
\hline$\beta_{11}$ & 0.058 & $(0.001)$ & -0.069 & $(0.001)$ \\
\hline$\beta_{12}$ & 0.045 & $(0.046)$ & -0.162 & $(0.001)$ \\
\hline$\beta_{12}^{*}$ & 0.037 & $(0.623)$ & -0.233 & $(0.009)$ \\
\hline$\beta_{13}$ & -0.021 & $(0.045)$ & 0.133 & $(0.001)$ \\
\hline$\beta_{13}^{*}$ & -0.086 & $(0.034)$ & 0.240 & $(0.008)$ \\
\hline \multirow[t]{2}{*}{$\delta$} & -1.591 & $(0.001)$ & -6.749 & $(0.001)$ \\
\hline & \multicolumn{4}{|c|}{ Conditional Variance Equation } \\
\hline$c_{11}$ & 0.033 & $(0.071)$ & 0.014 & $(0.101)$ \\
\hline$c_{22}$ & -0.006 & $(0.094)$ & -0.001 & $(0.078)$ \\
\hline$c_{33}$ & 0.006 & $(0.085)$ & 0.004 & $(0.062)$ \\
\hline$g_{11}$ & 0.967 & $(0.001)$ & -0.964 & $(0.001)$ \\
\hline$g_{21}$ & -0.003 & $(0.001)$ & -0.079 & $(0.094)$ \\
\hline$g_{21}^{*}$ & 0.002 & $(0.001)$ & 0.072 & $(0.092)$ \\
\hline$g_{22}$ & 0.978 & $(0.001)$ & 0.980 & $(0.001)$ \\
\hline$g_{31}$ & -0.003 & $(0.001)$ & -0.082 & $(0.003)$ \\
\hline$g_{31}^{*}$ & -0.004 & $(0.001)$ & 0.062 & $(0.229)$ \\
\hline$g_{33}$ & 0.991 & $(0.001)$ & 0.993 & $(0.001)$ \\
\hline$a_{11}$ & -0.231 & $(0.002)$ & -0.223 & $(0.001)$ \\
\hline$a_{21}$ & -0.023 & $(0.023)$ & -0.005 & $(0.012)$ \\
\hline$a_{21}^{*}$ & -0.024 & $(0.048)$ & 0.003 & $(0.035)$ \\
\hline$a_{22}$ & 0.024 & $(0.001)$ & 0.126 & $(0.001)$ \\
\hline$a_{31}$ & 0.027 & $(0.037)$ & -0.065 & $(0.045)$ \\
\hline$a_{31}^{*}$ & 0.143 & $(0.003)$ & -0.046 & $(0.036)$ \\
\hline$a_{33}$ & 0.139 & $(0.001)$ & 0.129 & $(0.001)$ \\
\hline LogLik & -11059.37 & & -9333.98 & \\
\hline$L B_{\text {Comm.,(10) }}$ & 4.3456 & & 10.564 & \\
\hline$L B_{\text {Comm.,(10) }}$ & 7.1291 & & 10.452 & \\
\hline
\end{tabular}

Note: See the notes to Table 2. 


\subsection{Discussion of the results}

In order to assess the adequacy of the estimated models, Ljung-Box portmanteau tests were performed on the standardized and squared residuals. Overall, the results indicate that the VAR-GARCH(1,1) specification captures satisfactorily the persistence in returns and squared returns of all the series considered. Causality effects in the conditional mean and variance vary in magnitude and sign across countries. Note that the signs on cross-market volatilities cannot be determined. The estimated VAR-GARCH $(1,1)$ models with the associated robust $p$-values and likelihood function values are presented in Tables $2-6$. We select the optimal lag length of the mean equation using the Schwarz information criterion.

The main findings can be summarized as follows. Concerning the effects of positive news on commodity returns $\left(\beta_{12}\right)$, we find positive causality for most commodities (but not significant at the standard 5\% significance level in the case of Aluminium, Copper, Palladium, Platinum and Soybeans), and negative causality for Gold and Silver.

Table 4. Estimated VAR-GARCH(1,1) model

\begin{tabular}{|c|c|c|c|c|}
\hline & \multicolumn{2}{|c|}{ Oil } & \multicolumn{2}{|c|}{ Palladium } \\
\hline & Coefficient & $p$-values & Coefficient & $p$-values \\
\hline & \multicolumn{4}{|c|}{ Conditional Mean Equation } \\
\hline$\alpha_{1}$ & -0.071 & $(0.347)$ & 0.041 & $(0.605)$ \\
\hline$\alpha_{2}$ & 1.723 & $(0.001)$ & 1.721 & $(0.001)$ \\
\hline$\alpha_{3}$ & 1.714 & $(0.001)$ & 1.711 & $(0.001)$ \\
\hline$\beta_{11}$ & -0.041 & $(0.005)$ & 0.081 & $(0.001)$ \\
\hline$\beta_{12}$ & 0.155 & $(0.049)$ & 0.035 & $(0.121)$ \\
\hline$\beta_{12}^{*}$ & 0.208 & $(0.046)$ & 0.118 & $(0.021)$ \\
\hline$\beta_{13}$ & -0.045 & $(0.712)$ & -0.015 & $(0.502)$ \\
\hline$\beta_{13}^{*}$ & -0.151 & $(0.341)$ & -0.162 & $(0.001)$ \\
\hline \multirow[t]{2}{*}{$\delta$} & -5.361 & $(0.004)$ & -3.034 & $(0.114)$ \\
\hline & \multicolumn{4}{|c|}{ Conditional Variance Equation } \\
\hline$c_{11}$ & 0.001 & $(0.001)$ & 0.178 & $(0.002)$ \\
\hline$c_{22}$ & -0.002 & $(0.001)$ & -0.002 & $(0.009)$ \\
\hline$c_{33}$ & 0.003 & $(0.001)$ & 0.003 & $(0.007)$ \\
\hline$g_{11}$ & -0.975 & $(0.001)$ & -0.958 & $(0.001)$ \\
\hline$g_{21}$ & 0.027 & $(0.166)$ & 0.005 & $(0.231)$ \\
\hline$g_{21}^{*}$ & -0.031 & $(0.234)$ & 0.004 & $(0.563)$ \\
\hline$g_{22}$ & 0.990 & $(0.001)$ & 0.885 & $(0.001)$ \\
\hline$g_{31}$ & 0.023 & $(0.446)$ & 0.007 & $(0.333)$ \\
\hline$g_{31}^{*}$ & -0.020 & $(0.786)$ & 0.011 & $(0.438)$ \\
\hline$g_{33}$ & 0.890 & $(0.001)$ & 0.991 & $(0.001)$ \\
\hline$a_{11}$ & -0.208 & $(0.001)$ & 0.259 & $(0.001)$ \\
\hline$a_{21}$ & -0.006 & $(0.254)$ & 0.012 & $(0.005)$ \\
\hline$a_{21}^{*}$ & 0.002 & $(0.697)$ & 0.017 & $(0.001)$ \\
\hline$a_{22}$ & 0.127 & $(0.001)$ & 0.128 & $(0.001)$ \\
\hline$a_{31}$ & -0.005 & $(0.398)$ & 0.013 & $(0.009)$ \\
\hline$a_{31}^{*}$ & 0.020 & $(0.687)$ & 0.014 & $(0.006)$ \\
\hline$a_{33}$ & 0.129 & $(0.001)$ & 0.131 & $(0.001)$ \\
\hline LogLik & -10687.85 & & -11855.65 & \\
\hline$L B_{\text {Comm.,(10) }}$ & 12.453 & & 11.329 & \\
\hline$L B_{\text {Comm.,(10) }}$ & 9.775 & & 10.764 & \\
\hline
\end{tabular}

Note: See the notes to Table 2. 
Table 5. Estimated VAR-GARCH(1,1) model

\begin{tabular}{|c|c|c|c|c|}
\hline & \multicolumn{2}{|c|}{ Platinum } & \multicolumn{2}{|c|}{ Silver } \\
\hline & Coefficient & $p$-values & Coefficient & $p$-values \\
\hline & \multicolumn{4}{|c|}{ Conditional Mean Equation } \\
\hline$\alpha_{1}$ & 0.043 & $(0.413)$ & 0.017 & $(0.788)$ \\
\hline$\alpha_{2}$ & 1.721 & $(0.001)$ & 1.718 & $(0.001)$ \\
\hline$\alpha_{3}$ & 1.711 & $(0.001)$ & 1.709 & $(0.001)$ \\
\hline$\beta_{11}$ & 0.033 & $(0.088)$ & -0.024 & $(0.161)$ \\
\hline$\beta_{12}$ & 0.002 & $(0.549)$ & -0.006 & $(0.012)$ \\
\hline$\beta_{12}^{*}$ & 0.182 & $(0.176)$ & -0.274 & $(0.026)$ \\
\hline$\beta_{13}$ & -0.011 & $(0.712)$ & 0.002 & $(0.027)$ \\
\hline$\beta_{13}^{*}$ & -0.159 & $(0.341)$ & 0.289 & $(0.048)$ \\
\hline \multirow[t]{2}{*}{$\delta$} & -2.126 & $(0.009)$ & -4.076 & $(0.043)$ \\
\hline & \multicolumn{4}{|c|}{ Conditional Variance Equation } \\
\hline$c_{11}$ & -0.001 & $(0.001)$ & -0.003 & $(0.067)$ \\
\hline$c_{22}$ & 0.005 & $(0.001)$ & 0.004 & $(0.564)$ \\
\hline$c_{33}$ & 0.003 & $(0.001)$ & 0.001 & $(0.331)$ \\
\hline$g_{11}$ & -0.966 & $(0.001)$ & -0.972 & $(0.001)$ \\
\hline$g_{21}$ & 0.026 & $(0.166)$ & -0.015 & $(0.443)$ \\
\hline$g_{21}^{*}$ & 0.003 & $(0.234)$ & 0.017 & $(0.776)$ \\
\hline$g_{22}$ & 0.991 & $(0.001)$ & 0.991 & $(0.001)$ \\
\hline$g_{31}$ & 0.009 & $(0.446)$ & -0.011 & $(0.123)$ \\
\hline$g_{31}^{*}$ & 0.019 & $(0.786)$ & 0.014 & $(0.353)$ \\
\hline$g_{33}$ & 0.990 & $(0.001)$ & 0.990 & $(0.001)$ \\
\hline$a_{11}$ & 0.227 & $(0.001)$ & 0.226 & $(0.001)$ \\
\hline$a_{21}$ & -0.023 & $(0.254)$ & -0.015 & $(0.001)$ \\
\hline$a_{21}^{*}$ & -0.057 & $(0.697)$ & -0.016 & $(0.001)$ \\
\hline$a_{22}$ & 0.125 & $(0.001)$ & 0.126 & $(0.001)$ \\
\hline$a_{31}$ & -0.021 & $(0.398)$ & 0.016 & $(0.001)$ \\
\hline$a_{31}^{*}$ & -0.012 & $(0.047)$ & 0.015 & $(0.001)$ \\
\hline$a_{33}$ & 0.129 & $(0.001)$ & 0.131 & $(0.001)$ \\
\hline LogLik & -10397.71 & & -11536.39 & \\
\hline$L B_{\text {Comm., (10) }}$ & 6.8961 & & 8.1413 & \\
\hline$L B_{\text {Comm.,(10) }}$ & 9.7875 & & 10.1267 & \\
\hline
\end{tabular}

Note: See the notes to Table 2.

For the latter two, the size of this negative effect increases (in absolute value) in the post-September 2008 period. As for the impact of negative news on commodities $\left(\beta_{13}\right)$, there appears to be negative and significant causality at the standard 5\% significance level for Aluminium, Corn and Wheat, whereas the effect on Gold and Silver is positive. All other commodities do not seem to be affected by news releases. The largest coefficient are those for Gold $(0.133)$ and Wheat $(-0.112)$. The post-September 2008 results indicate an increase in the effects of negative news on Aluminium, Corn, Gold, Palladium, Silver and Wheat with the corresponding coefficient (in absolute value) almost doubling (on average) in size in the second sub-sample. Instead, neither negative nor positive news appear to affect Copper, Platinum and Soybeans. These patterns appear to have been reinforced by the recent financial crisis.

Concerning the conditional variance equations, the estimated 'own-market' coefficients are statistically significant, and the estimates of $g_{11}$ suggest a high degree of persistence. The pattern is substantially different compared with the first moment for the commodities considered, with positive and negative news volatility having a significant impact on the volatility of commodity returns (remember that the sign cannot be established) in the case 
Table 6. Estimated VAR-GARCH(1,1) model

\begin{tabular}{|c|c|c|c|c|}
\hline & \multicolumn{2}{|c|}{ Soybeans } & \multicolumn{2}{|c|}{ Wheat } \\
\hline & Coefficient & $p$-values & Coefficient & $p$-values \\
\hline & \multicolumn{4}{|c|}{ Conditional Mean Equation } \\
\hline$\alpha_{1}$ & 0.037 & $(0.401)$ & 0.021 & $(0.707)$ \\
\hline$\alpha_{2}$ & 1.722 & $(0.001)$ & 1.721 & $(0.001)$ \\
\hline$\alpha_{3}$ & 1.711 & $(0.001)$ & 1.715 & $(0.001)$ \\
\hline$\beta_{11}$ & -0.019 & $(0.195)$ & 0.001 & $(0.675)$ \\
\hline$\beta_{12}$ & 0.033 & $(0.432)$ & 0.082 & $(0.043)$ \\
\hline$\beta_{12}^{*}$ & 0.116 & $(0.312)$ & 0.249 & $(0.002)$ \\
\hline$\beta_{13}$ & -0.046 & $(0.223)$ & -0.112 & $(0.016)$ \\
\hline$\beta_{13}^{*}$ & -0.129 & $(0.111)$ & -0.302 & $(0.001)$ \\
\hline \multirow[t]{2}{*}{$\delta$} & -2.401 & $(0.045)$ & -1.414 & $(0.076)$ \\
\hline & \multicolumn{4}{|c|}{ Conditional Variance Equation } \\
\hline$c_{11}$ & 0.001 & $(0.001)$ & -0.002 & $(0.046)$ \\
\hline$c_{22}$ & 0.001 & $(0.002)$ & 0.006 & $(0.007)$ \\
\hline$c_{33}$ & -0.005 & $(0.034)$ & 0.002 & $(0.034)$ \\
\hline$g_{11}$ & -0.965 & $(0.003)$ & -0.981 & $(0.001)$ \\
\hline$g_{21}$ & -0.051 & $(0.028)$ & 0.001 & (0.978) \\
\hline$g_{21}^{*}$ & -0.048 & $(0.001)$ & 0.006 & $(0.001)$ \\
\hline$g_{22}$ & 0.990 & $(0.001)$ & 0.088 & $(0.001)$ \\
\hline$g_{31}$ & 0.048 & $(0.001)$ & -0.005 & $(0.049)$ \\
\hline$g_{31}^{*}$ & 0.043 & $(0.038)$ & -0.011 & $(0.086)$ \\
\hline$g_{33}$ & 0.992 & $(0.001)$ & 0.993 & $(0.001)$ \\
\hline$a_{11}$ & 0.214 & $(0.001)$ & 0.174 & $(0.001)$ \\
\hline$a_{21}$ & -0.008 & $(0.078)$ & 0.011 & $(0.041)$ \\
\hline$a_{21}^{*}$ & -0.002 & $(0.112)$ & 0.010 & $(0.038)$ \\
\hline$a_{22}$ & 0.126 & $(0.001)$ & 0.132 & $(0.001)$ \\
\hline$a_{31}$ & 0.012 & $(0.021)$ & 0.012 & $(0.042)$ \\
\hline$a_{31}^{*}$ & 0.007 & $(0.041)$ & 0.010 & $(0.011)$ \\
\hline$a_{33}$ & 0.129 & $(0.001)$ & 0.131 & $(0.001)$ \\
\hline LogLik & -10791.41 & & -11491.26 & \\
\hline$L B_{\text {Comm.,(10) }}$ & 4.2231 & & 5.1514 & \\
\hline$L B_{\text {Comm.,(10) }}$ & 5.6114 & & 9.3715 & \\
\hline
\end{tabular}

Note: See the notes to Table 2.

of Aluminium, Copper, Corn, Palladium, Silver and Wheat. The causality effect (in absolute value) for negative (measured by $a_{21}$ ) and for positive (measured by $a_{31}$ ) news volatility has the same size for all commodities examined except Gold, with negative news volatility having a larger effect than positive news volatility in this case. Furthermore, there is evidence of the 2008 crisis affecting the causality-in-variance dynamics. In particular, the post-crisis negative news volatility effect doubled at least for the non-agricultural commodities compared with the pre-September 2008 period, with the largest increase occurring for corn $\left(a_{31}^{*}=0.143\right)$. Finally, the exogenous variable included in the model is statistically significant for all commodities, its estimated coefficient indicating a negative exchange rate effect, as one would expect.

\section{CONCLUSIONS}

This paper has adopted a multivariate GARCH approach to examine both mean and volatility spillovers between macro news and commodity returns (Gold, Corn, Wheat, Soybeans, Silver, Platinum, Palladium, Copper, 
Aluminium and Crude Oil) over the period 01/01/2001-26/09/2014. The chosen specification also controls for the effect of the exchange rate. The novel contribution of the analysis to the existing literature is twofold: it provides new evidence on volatility linkages, and also on the effects of the recent financial crisis. The results can be summarized as follows. Mean spillovers running from news to commodity returns are positive with the exception of Gold and Silver. This might reflect the fact that latter commodities are seen as a 'safe heaven' (as well as a store of value). This asymmetric response is a common finding in the literature (e.g. Roache and Rossi, 2009). Volatility spillovers are bigger in size and affect most commodity returns. Both first-moment and second-moment linkages are stronger in the post-September 2008 period. This is consistent with the evidence provided by previous studies that commodities such as gold are more sensitive to news releases during recessions, when there is greater uncertainty (e.g. Hess et al., 2008).

Overall, our findings confirm that commodities, despite not being financial assets, respond to macro news (especially their volatility) and also suggest that the global financial crisis has strengthened such linkages. Newspaper headlines are confirmed to be an important driver of the response of prices to news releases: taking them into account is crucial to analysing the linkages between real sector news and prices, which appear to have become even stronger because the start of the global financial crisis in the case of commodity prices as well. Further, the evidence that the relationship between news and commodity prices is not stable over time is of considerable interest to policy makers aiming at stabilizing markets. It is also relevant for market participants for risk and portfolio management purposes. Finally, it should be acknowledged that one of the limitations of the present study is that it does not control for news reported in consumer rather than exporter countries. Given the high frequency of the data used, it would not have been possible to do so, but it would be interesting to investigate such issues in future research adopting a different modelling approach.

\section{NOTES}

1. Evidence on the direction of causality, running from media to stock market variables, is provided by both Engelberg and Parsons (2011) and Peress (2011)

2. The model is based on the GARCH(1,1)-BEKK representation proposed by Engle and Kroner (1995).

3. The subscript $i$ refers to the ten commodities under investigation.

4. The parameters $\left(a_{21}\right)$ and $\left(a_{31}\right)$ in Equation (3) measure the causality effect of positive and negative news volatility respectively, whereas $\left(a_{21}+a_{21}^{*}\right)$ and $\left(a_{31}+a_{31}^{*}\right)$ the possible effects of the 2008 financial crisis.

5. Neutral and mixed news, which have been found not to be significant in previous studies, have not been considered given the aim of this paper.

Although news were not classified by commodity demand or supply, we consider news reported in the US and the Eurozone since these are the main importers/consumers of commodities. It would not have been possible to control for the supply side because statistics on news in those countries were rather limited and discontinuous.

6. The joint restrictions $H_{05}-H_{08}$ are tested by means of a Wald test.

\section{REFERENCES}

Andersen TG, Bollerslev T, Diebold FX, Vega C. 2005. Real-time price discovery in stock, bond and foreign exchange markets. NBER Working Paper no 11312.

Antweiler W, Frank MZ. 2004. Is all that talk just noise? The information content of Internet stock message boards. Journal of Finance 59: 1259-1293.

Balduzzi P, Elton EJ, Green TC. 2001. Economic news and bond prices: evidence from the US Treasury market. Journal of Financial and Quantitative Analysis 36: 523-543.

Barnhart SW. 1989. The effects of macroeconomic announcements on commodity prices. American Journal of Agricultural Economics 71(2): 389-403.

Beetsma R, Giuliodori M, de Jong F, Widijanto D. 2013. Spread the news: the impact of news on the European sovereign bond market during the crisis. Journal of International Money and Finance 34: 83-101.

Birz G, Lott JR. 2011. The effect of macroeconomic news on stock returns: new evidence from newspaper coverage. Journal of Banking and Finance 35: 2791-2800.

Bollerslev T, Wooldridge M. (1992). Quasi-maximum likelihood estimation and inference in dynamic models with time-varying covariances. Econometric Reviews 11(2): 143-172.

Boyd JH, Hu J, Jagannathan R. 2005. The stock market's reaction to unemployment news: why bad news is usually good for stocks. Journal of Finance 60: 649-670.

Brenner M, Pasquariello P, Subrahmanyam M. 2009. On the Volatility and Comovemenr of U.S. Financial Markets around Macroeconomic News Announcements. miemo, Stern School of Business: New York University.

Cai J, Cheung Y-L, Wong MCS. 2001. What moves the gold market)? Journal of Futures Markets 21(3): 257-278.

Cakan E, Doytch N, Upadhyaya KP. (2015). Does U.S. macroeconomic news make emerging financial markets riskier? Borsa Istanbul Review 15(1): 37-43. 
Campbell JY, Grossman SJ, Wang J. 1993. Trading volume and serial correlation in stock returns. Quarterly Journal of Economics 108: 905-939.

Caporale GM, Spagnolo F, Spagnolo N. 2014a. Macro news and stock returns in the Euro area: a VAR-GARCH-in-means analysis, CESifo working paper no. 4912.

Caporale GM, Spagnolo F, Spagnolo N. 2014b. Macro news and bond yield spreads in the euro area. CESifo Working Paper no. 5008 .

Chen N. 1991. Financial investment opportunities and the macroeconomy. Journal of Finance 46: 529-554.

Cornell B. (1983). The money supply announcements puzzle: review and interpretation. American Economic Review 73: 644-657.

Coval JD, Shumway T. 2001. Is sound just noise? Journal of Finance 56: 1887-1910.

De Long JB, Shleifer A, Summers LH, Waldmann RJ. 1990. Noise trader risk in financial markets. Journal of Political Economy 98: 703-738.

Engelberg JE, Parsons CA. 2011. The causal impact of media in financial markets. Journal of Finance 66(1): 67-97.

Engle RF, Kroner KF. 1995. Multivariate simultaneous generalized ARCH. Econometric Theory 11: 122-150.

Engle RF, Susmel R. 1993. Common volatility in international equity markets. Journal of Business and Economic Statistics 11(2): $167-176$

Fang L, Peress J. 2009. Media coverage and the cross-section of stock returns. Journal of Finance 64(5): $2023-2052$.

Frankel JA. 2008. The effect of monetary policy on real commodity prices, Asset Prices and Monetary Policy, University of Chicago Press, pp. 291-327.

Frankel JA, Hardouvelis GA. 1985. Commodity prices, money surprises and fed credibility. Journal of Money, Credit and Banking 17(4): 425-438.

Fuss R, Grabellus M, Mager F, Stein M. 2015. Something in the air: information density, news surprises, and price jumps, working paper, Switzerland.

Ghura D. 1990. How commodity prices respond to macroeconomic news, World Bank PRE working paper no. 354.

Gürkaynak R.F, Sack B, Swanson E. 2005. The sensitivity of long-term interest rates to economic news: evidence and implications for macroeconomic models. The American Economic Review 95(1): 425-436.

Hanousek J, Kocenda E, Kutan AM. 2009. The reaction of asset prices to macroeconomic announcements in the new EU markets: evidence from intraday data. Journal of Financial Stability 5(2): 199-219.

Hess D, Huang H, Niessen A. 2008. How do commodity futures respond to macroeconomic news? Journal of Financial Markets and Portfolio Management 22(2): 127-146.

Huang X. 2015. Macroeconomic news announcements, systemic risk, financial market volatility and jumps, finance and economics discussion series 2015-097. Washington: Board of Governors of the Federal Reserve System.

Kilian L, Vega C. 2008. Do energy prices respond to US macroeconomics news? A test of the hypothesis of predetermined energy prices, Federal Reserve International Discussion Paper no. 957.

Kocenda E, Hanousek J. 2011. Foreign news and spillovers in emerging European stock markets. Review of International Economics 19(1): 170-188.

Ljung GM, Box GEP. 1978. On a measure of lack of fit in time series models. Biometrika 65: $297-303$.

McQueen G, Roley VV. 1993. Stock prices, news and business conditions. Review of Financial Studies 92: $307-328$.

Merton R. 1987. A simple model of capital market equilibrium with incomplete information. Journal of Finance 42: 483-510.

Pearce DK, Roley VV. 1983. The reaction of stock prices to unanticipated changes in money: a note. Journal of Finance 38: 1323-1333.

Pearce DK, Roley VV. 1985. Stock prices and economic news. Journal of Business 58: 49-67.

Peress J. 2011. The Impact of Media in Financial Markets: Evidence from Newspaper Strikes. mimeo: INSEAD, Paris.

Pericoli M, Veronese G. 2016. Forecaster heterogeneity, surprises and financial markets, WP 030416, Federal Reserve Bank of Atlanta.

Roache SK, Rossi M. 2009. The effects of economic news on commodity prices: is gold just another commodity? Quarterly Review of Economic and Finance 50: 377-385.

Tetlock PC. 2007. Giving content to investor sentiment: the role of media in the stock market. Journal of Finance 62(3): 1139-1168.

Tetlock PC, Saar-Tsechansky M, Macskassy S. 2008. More than words: quantifying language to measure firms 'fundamentals. Journal of Finance 63: 1437-1467. 